E-ISSN: 2502-6674

P-ISSN: 2502-6666

http://ojs.uho.ac.id/index.php/p_sejarah_uho

\title{
PENERAPAN MODEL PEMBELAJARAN CTL DALAM PEMBELAJARAN SOSIOLOGI UNTUK MENINGKATKAN HASIL BELAJAR SISWA KELAS XI IPS-3 SMA NEGERI 1 WANGI-WANGI ${ }^{1}$
}

\author{
Oleh \\ Femi $^{2}$, Irawaty $^{3}$
}

\begin{abstract}
ABSTRAK: Tujuan penelitian adalah untuk: 1) Meningkatkan aktivitas belajar sosiologi pada siswa kelas XI IPS-3 SMA Negeri I Wangi-Wangi melalui penerapan model pembelajaran CTL 2) Meningkatkan efektivitas mengajar sosiologi pada guru kelas XI IPS-3 SMA Negeri I WangiWangi melalui penerapan model pembelajaran CTL 3) Meningkatkan hasil belajar sosiologi pada siswa kelas XI IPS-3 SMA Negeri I Wangi-Wangi melalui penerapan model pembelajaran CTL. Subjek penelitian ini adalah guru dan seluruh siswa kelas XI IPS-3 SMA Negeri I Wangi-Wangi sebanyak 29 siswa.

Data yang diperoleh dari penelitian ini adalah aktivitas yang diperoleh dari lembar observasi dan hasil belajar siswa yang diukur melalui tes siklus. Analisis data yang dilakukan dengan statistik deskriptif. Dari hasil analisis data diproleh kesimpulan bahwa: 1) Aktivitas belajar siswa pada siklus I mencapai $70 \%$ yang belum mencapai indikator kinerja, pada siklus II meningkat menjadi $100 \%$. Telah mencapai indikator kinerja 2) Efektivitas mengajar guru pada siklus I mencapai $83 \%$ belum mencapai indikator kinerja yang telah ditetapkan, pada siklus II meningkat menjadi 100\% telah mencapai indikator kinerja. 3) Hasil belajar sosiologi siswa pada siklus I nilai rata-rata mencapai 69 sedangkan pada siklus II nilai rata-rata mencapai 88. Peningkatan hasil belajar siswa pada siklus I mencapai $66 \%$ atau 19 orang dari 29 siswa yang tuntas secara klasikal dan $34 \%$ atau 10 orang yang tidak tuntas secara klasikal dan pada siklus II hasil belajar sosiologi siswa mencapai $93 \%$ atau 27 orang dari 29 siswa yang tuntas secara klasikal dan $7 \%$ atau 2 orang yang tidak tuntas secara klasikal .
\end{abstract}

\section{Kata Kunci: Aktivitas, Efektivitas, Hasil Belajar}

\section{PENDAHULUAN}

Proses belajar mengajar merupakan suatu sistem yang komponennya saling berinteraksi sebagai satu kesatuan. Komponen sistem pembelajaran itu antara lain: siswa, guru, tujuan pembelajaran, materi pembelajaran, metode, media, saran dan prasarana, evaluasi dan lingkungan pembelajaran (Hendyat, 2005:143)

Pembelajaran terpusat pada guru menemukan beberapa kelemahan. Kelemahan tersebut dapat dilihat pada saat berlangsungnya proses pembelajaran di kelas, interaksi aktif antara siswa dengan guru atau siswa dengan siswa jarang terjadi. Siswa kurang terampil menjawab pertanyaan atau bertanya tentang konsep yang diajarkan. Pengetahuan yang didapat bukan dibangun sendiri secara bertahap oleh siswa atas dasar pemahaman sendiri. Karena siswa jarang menemukan jawaban atas konsep yang dipelajari. Setelah dilakukan evaluasi terhadap hasil belajar siswa ternyata dengan pendekatan pembelajaran seperti itu hasil belajar siswa belum maksimal. Sani (2013: 89) model pembelajaran merupakan kerangkakonseptual berupa pola prosedur sistematik yang dikembangkan berdasarkanteori dan di gunakan dalam mengorganisasikan proses belajar mengajar untukmencapai tujuan belajar.

Kondisi yang demikian juga terjadi pada siswa kelas XI IPS-3 SMA Negeri 1 WangiWangi. Ketika pembelajaran sosiologi, metode yang digunakan guru adalah metode ceramah dan tanya jawab. Sehingga siswa hanya mencatat, memperhatikan mendengarkan dan menjawab.

\footnotetext{
${ }^{1}$ Disandur Dari hasil Penelitian

${ }^{2}$ Alumni Jurusan Pendidikan Sejarah

${ }^{3}$ Dosen FKIP UHO
} 
E-ISSN: 2502-6674

P-ISSN: 2502-6666

http://ojs.uho.ac.id/index.php/p_sejarah_uho

Metode demikian ternyata belum bisa membuat peserta didik menjadi aktif dan paham terhadap materi yang disampaikan. Karena ketika diberi soal, masih ada sebagian siswa yang kesulitan dalam mengerjakannya. Hal ini tampak pada pencapaian nilai akhir siswa yang jika dirata-rata nilainya masih banyak yang belum memenuhi KKM yang telah ditentukan yaitu 70 (Arikunto, $2006: 11)$.

Rendahnya pencapaian nilai akhir siswa ini, menjadi indikasi bahwa pembelajaran yang dilakukan selama ini belum efektif. Nilai akhir dari evaluasi belajar belum mencakup penampilan dan partisipasi siswa dalam pembelajaran, hingga sulit untuk mengukur keterampilan siswa. Pemilihan strategi pembelajaran yang tepat adalah salah satu cara untuk mengatasi permasalahan di atas. Pemilihan strategi pembelajaran idealnya disesuaikan dengan sifat materi, karakteristik peserta didik, lingkungan sekolah. Penggunaan strategi pembelajaran yang tepat tentunya dapat membarikan motivasi untuk belajar dan merangsang siswa untuk belajar aktif. Strategi pembelajaran CTL dianggap salah satu strategi pembelajaran yang bagus untuk meningkatkan motivasi belajar siswa dan keaktifan siswa.

Menurut Nurhadi dalam Muslich (2009:41) mengemukakan pembelajaran CTL adalah konsep belajar yang membantu guru mengaitkan antara materi pembelajaran dengan situasi dunia nyata siswa dan mendorong siswa membuat hubungan antara pengetahuan yang dimilikinya dengan penerapannya dalam kehidupan mereka sehari-hari. Dalam konteks CTL belajar bukan hanya sekedar mendengarkan dan mencatat, akan tetapi belajar merupakan suatu proses berpengalaman secara langsung. Melalui proses berpengalaman itu diharapkan perkembangan siswa terjadi secara utuh, yang tidak hanya berkembang dalam aspek kognitif saja, tetapi juga aspek afektif dan juga psikomotorik. Dengan membuat hubungan antara pengetahuan yang telah dimiliki oleh siswa danpenerapannya dalam kehidupan sehari-hari, maka siswa mudah memahami konsep belajar. Dengan model pembelajaran CTL, siswa bekerja dan mengalami, bukan mentransfer pengetahuan dari guru ke siswa semata. Pendekatan CTL merupakan strategi yang dikembangkan dengan tujuan agar pembelajaran berjalan lebih produktif dan bermakna, dengan siswa diajak bekerja dan mengalami, siswa mudah memahami konsep suatu materi dan nantinya siswa diharapkan dapat menggunakan daya nalarnya untuk menyelesaikan masalah-masalah yang ada. Pendekatan pembelajaran yang dilakukan oleh guru merupakan suatu upaya yang harus diciptakan secara teratur untuk mewujudkan keberhasilan dari proses kegiatan belajar mengajar di kelas. Keberhasilan model pembelajaran yang dilakukan oleh seorang guru dapat diketahui dengan adanya persepsi yang berasal dari siswa sebagai obyek dalam kegiatan belajar di kelas. Persepsi yang dimaksud adalah persepsi dari siswa itu sendiri baik itu persepsi yang bersifat positif maupun negatif. $C T L$ merupakan suatu konsepsi yang membantu guru mengaitkankonten pelajaran dengan situasi dunia nyata dan memotivasi peserta didikmembuat hubungan antara pengetahuan dan penerapannya dalam kehidupanmereka sebagai anggota keluarga, warga negara, dan/ atau tenaga kerja (Sani, 2013: 92).

Kondisi yang demikian juga terjadi pada siswa kelas XI IPS-3 SMA Negeri 1 WangiWangi. Ketika pembelajaran sosiologi, metode yang digunakan guru adalah metode ceramah dan tanya jawab. Sehingga siswa hanya mencatat, memperhatikan mendengarkan dan menjawab. Metode demikian ternyata belum bisa membuat peserta didik menjadi aktif dan paham terhadap materi yang disampaikan. Karena ketika diberi soal, masih ada sebagian siswa yang kesulitan dalam mengerjakannya. Hal ini tampak pada pencapaian nilai akhir siswa yang jika dirata-rata nilainya masih banyak yang belum memenuhi KKM yang telah ditentukan yaitu 70 .

\section{METODE PENELITIAN}

Penelitian ini dilaksanakan di Sekolah Menengah Atas (SMA) Negeri 1 Wangi-Wangi Kelurahan Pongo Kecamatan Wangi-Wangi Kabupaten Wakatobi Provisi Sulawesi Tenggara. Subyek dalam penelitian ini adalah siswa SMA Negeri 1 Wangi-Wangi. Peneliti mengambil satu kelas yang bermasalah, yaitu kelas XI IPS-3 yang berjumlah 29 orang, yaitu terdiri atas 18 orang laki-laki dan 11 orang perempuan. Pemilihan kelas tersebut didasari oleh rendahnya aktivitas dan hasil belajar sosiologi. Jenis penelitian ini adalah penelitian tindakan kelas (class roomaction 
E-ISSN: 2502-6674

P-ISSN: 2502-6666

http://ojs.uho.ac.id/index.php/p_sejarah_uho

research)yang dilakukan dengan tujuan untuk meningkatkan mutu praktik pembelajaran di kelasnya. Karena PTK berfokus pada kelas atau pada proses pembelajaran yang terjadi di kelas, dan bukan pada input (RPP, materi, dll) ataupun output (hasil belajar). PTK harus bertujuan atau mengenai hal-hal yang terjadi di kelas.

Untuk menajawab permasalahan dalam penelitian ini, ada beberapa faktor yang harus diteliti. Faktor-faktor tersebut adalah sebagai berikut: (1) Faktor siswa, yakni partisipasi siswa dalamproses pembelajaran dan penguasaan materi. (2) Faktor guru, yakni kemampuan guru dalam mengorganisasikan proses pembelajaran, baik cara mempersiapkan materi maupu menerapkan model pembelajaran CTL, mulai dari membuka pelajaran, kegiatan inti, kesimpulan sampai pada evaluasi. (3) Faktor pencapaian (hasil belajar) yakni output pembelajaran yang diperoleh dari tes hasil belajar siswa setelah melakukan serangkaian kegiatan belajar yang diorganisasikan oleh guru.

Prosedur penelitian ini terdiri dari 2 siklus. Tiap siklus terdidri dari 3 kali pertemuan. Masing-masing terdiri dari 2 kali pertemuan untuk pelaksanan pembelajaran dan satu 1 pertemuan untuk tes hasil belajar. Langkah-langkah pelaksanaan pada setiap siklus adalah (1) perencanaan; (2) pelaksanaan; (3) observasi dan evaluasi; (4) refleksi. Jenis dan Sumber Data dalam penelitian ini adalah (1) Jenis Dataadalah data kualitatif dan kuantitatif. Kualitatif berupa kegiatan proses pembelajarna aktivitas belajar siswa dan aktivitas guru sedangkan data kuantitatif berupa nilai asil belajar siswa. (2) Sumber Data adalah siswa kelas XI IPS-3 SMA Negeri 1 Wangi-Wangi dan guru yang mengajar matapelajaran sosiologi di kelas XI IPS SMA Negeri 1 Wangi-Wangikelas XI IPS SMA Negeri 1 Wangi-Wangi. Teknik Pengumpulan Data (1) Observasi, (2) Tes Hasil Belajar.

Teknik analisis data dalam penelitian ini menggunakan teknik analisis kuantitatif dengan teknik analisis deskriptif yaitu menentukan persentase peningkatan, peningkatan persentase aktivitas belajar siswa dan menentukan nilai rata-rata siswa serta menggunakan persentase hasil belajar siswa. Adapun rumus statistik analisis kuantitatif dalam penelitian ini adalah sebagai berikut:

1. Rumus Persentase Aktivitas Belajar Siswa

$\%$ Aktivitas Siswa $=\frac{\text { skor perolehan aktivitas belajar siswa }}{\text { skor maksimum }} \times 100 \%($ Memes, 2001:36)

2. Rumus Persentase Efektivitas Mengajar Guru

$\%$ Efektivitas Mengajar Guru= $\frac{\text { skor perolehan efektifitas mengajar guru }}{\text { skor maksimum }} \times 100 \%$ (Memes, 2001:34)

3. Menentukan Nilai Rata-Rata

$$
\begin{array}{ll}
\bar{X}=\frac{\sum X i}{n} & \\
\text { Keterangan : } & \\
\bar{X} & =\text { Nilai Rata-Rata Siswa } \\
\sum \mathrm{Xi} & =\text { Jumlah Nilai Siswa } \\
\mathrm{n} & =\text { Jumlah Sampel (Sugiyono, 2006:41) }
\end{array}
$$

4. Menentukan Persentase Ketuntasan Hasil Belajar Siswa

Presentase Ketuntasan $=\frac{\sum X}{n} \times 100 \%$

Keterangan :

$\sum \mathrm{X}=$ Banyaknya Siswa Yang Tuntas

$\mathrm{n} \quad=$ Jumlah Sampel (Sugiyono, 2006:43)

Indikator keberhasilan pada penelitian tindakan kelas ini ditandai dengan : (1) Aktivitas belajar siswa dianggap tuntas apabila realitas keberhasilan telah mencapai $90 \%$ siswa aktif dalam pembelajaran. (2) Efektifitas mengajar guru dianggap tuntas apabila telah mencapai $90 \%$ skenario pembelajaran telah dilaksanakan dengan baik (3) Hasil belajar dinyatakan tuntas apabila $80 \%$ siswa telah mencapai KKM yaitu 70. 
E-ISSN: 2502-6674

P-ISSN: 2502-6666

http://ojs.uho.ac.id/index.php/p_sejarah_uho

\section{HASIL PENELITIAN DAN PEMBAHASAN}

\section{A. Hasil Penelitian}

\section{Pelaksanaan Tindakan Siklus I}

\section{Data Aktivitas Belajar Siswa}

Data mengenai aktivitas siswa kelas XI IPS-3 SMA Negeri I Wangi-Wangi selama pelaksanaan pembelajaran menggunakan model pembelajaran CTL diperoleh dengan menggunakan lembar observasi aktivitas siswa dengan cara memberikan skor keterlaksanaan pada setiap aspek aktivitas

Pada siklus I aktivitas siswa yang tidak terlaksana yaitu aktivitas nomor 7,8 dan 10 dimanaSiswa bertanya mengenaimateri yang yang belum dipahami, Siswa berpikir mengenai materi permasalahan yang di bahas dan Siswa berani mengemukakan pendapat tentang materi yang telah diterima.selain dari nomor 7,8 dan 10 semua aktivitas siswa dapat terlaksana pada nomor 1, 2, 3, 4, 5, 6, dan 9, dimana Siswa menyampaikan salam,Siswa mempersiapkan alat tulis dan sebagainya, Siswa menyahut ketika namanya di panggil, Siswa memperhatikan/mencatat tujuan pembelajaran yang harus di capai dalam proses pembelajaran, Siswa mendengarkan apa yang disampaikan guru, Siswa mendengarkan materi yang akan di bahas, Siswa menyimak dan memperhatiakan vidio yang di tampilkan melalui media infocusHal ini belum berhasil maka peneliti akan melanjutkan ke siklus berikutnya yaitu siklus II.

\section{Data Efektivitas Megajar Guru}

Gambaran aktivitas guru dalam proses belajar mengajar dengan menggunakan model pembelajaran CTL pada mata pelajaran sosiologi dapat diperoleh dengan menggunakan lembar observasi evektivitas mengajar guru pada tiap siklusnya. Pada siklus I efektivitas mengajar guru belum berhasil karena masih ada beberapa kegiatan guru yang belum dapat terlaksana yaitu pada efektivitas nomor 4 dan 11 yaitu Menyampaikan tujuan pembelajaran yang harusdicapai dalam proses pembelajaran dan Guru memberikan informasi tentang materi yang akan dibahas minggu depan dan mengingatkan pesertadidik untuk mempelajari materi dulu di rumah sebagai tugas. Sedangkan aspek efektivitas yang sudah terlaksana dengan baik yaitu nomor 1, 2, 3, 5, 6, 7, 8, 9, 10 dan 12.

\section{Data Hasil Belajar Siswa}

Data hasil belajar sosiologi pada kelas XI IPS-3 diperoleh dengan menggunakan lembar tes hasil belajar siswa berupa soal uraian yang diberikan pada setiap akhir siklus.. Berdasarkan hasil analisis deskriptif terhadap hasil belajar siswa pada siklus I diperoleh data hasil sebagaimana yang disajikan pada tabel 3. Dari tabel 3 analisis hasil belajar pada siklus I setelah menggunakan model pembelajaran CTL rata-rata hasil belajar siswa adalah 69 dimana 19 orang tuntas secara individu dan 10 orang lainnya tidak tuntas secara individu. Sedangkan ketuntasan secara klasikal $\frac{19}{29} \times 100 \%$ = 66\% dari 29 siswa yang mengikuti tes. Hal ini berarti pada siklus I belum berhasil, maka akan dilanjutkan pada siklus berikutnya yaitu siklus II.

Tabel 1. Analisis Ketuntasan Hasil Belajar Siswa pada Pembelajaran Siklus I

\begin{tabular}{|c|c|c|}
\hline Ketuntasan & Jumlah Siswa & Persentase (\%) \\
\hline Tuntas & 19 & $66 \%$ \\
\hline Tidak Tuntas & 10 & $34 \%$ \\
\hline Jumlah & 29 & $100 \%$ \\
\hline
\end{tabular}

Sumber Data: Diolah dari data penelitian, tahun 2019

Dari tabel 4 diatas, terlihat bahwa jika dianalisis secara persentase makaketuntasan belajar siswa mencapai 66\%. Dengan demikian maka indikator kinerja siswa belum mencapai target dimana indikator kinerja yang ditentukan yaitu $80 \%$ 
E-ISSN: 2502-6674

P-ISSN: 2502-6666

http://ojs.uho.ac.id/index.php/p_sejarah_uho

\section{Pelaksanaan Tindakan Siklus II}

\section{Data Aktivitas Belajar Siswa}

Data mengenai aktivitas siswa kelas XI IPS-3 SMA Negeri I Wangi-Wangi selama pelaksanaan pembelajaran menggunakan model pembelajaran CTL diperoleh dengan menggunakan lembar observasi aktivitas siswa dengan cara memberikan skor keterlaksanaan pada setiap aspek aktivitas. Pada siklus II terlihat bahwa semua aktivitas yang dinilai sudah mengalami peningkatan. Pada siklus II ini semua aktivitas siswa sudah terlaksana dengan baik termaksut pada aktivitas siswa nomor 7,8 dan 10 sudah mengalami peningkatan dan pada aktivitas siswa nomor 1, 2, 4, 5, 6, dan 9 semakin meningkat lagi. Pada siklus II ini dari semua aspek aktivitas siswa yang diobservasi telah mengalami peningkatan dengan baik secara keseluruhan rata-rata aktivitas siswa sudah meningkat pada siklus II ini.

\section{Data Efektivitas Mengajar Guru}

Gambaran aktivitas guru dalam proses belajar mengajar dengan menggunakan model pembelajaran CTL pada mata pelajaran sosiologi dapat diperoleh dengan menggunakan lembar observasi evektivitas mengajar guru pada tiap siklusnya. Pada siklus II ini terlihat bahwa setiap efektivitas yang dinilai telah mengalami peningkatan. Pada siklus II efektivitas- efektivitas guru sudah semakin meningkat dimana efektivitas yang belum terlaksana dengan baik mengalami peningkatan dan pada aspek-aspek lainnya juga mengalami peningkatan pada siklus II. Pada siklus II ini dari semua aspek aktivitas mengajar guru yang diobservasi telah mengalami peningkatan yang baik karena aktivitas mengajar guru meningkat.

\section{Data Hasil Belajar Siswa}

Data hasil belajar sosiologi pada kelas XI IPS-3 diperoleh dengan menggunakan lembar tes hasil belajar siswa berupa soal uraian yang diberikan pada setiap akhir siklus II. Berdasarkan hasil analisis deskriptif terhadap hasil belajar siswa pada siklus II diperoleh data hasil analisis hasil belajar pada siklus II setelah menggunakan model pembelajaran CTL rata-rata hasil belajar siswa adalah 88 dimana 27 orang tuntas secara individu dan 2 orang lainnya tidak tuntas secara individu. Sedangkan ketuntasan secara klasikal $\frac{27}{29} \times 100 \%=93 \%$ dari 29 siswa yang mengikuti tes. Hal ini berarti pada siklus II setelah menggunakan model pembelajaran CTL telah mencapai keberhasilan secara klasikal.

Tabel 2. Analisis Ketuntasan Hasil Belajar Siswa pada Pembelajaran Siklus I

\begin{tabular}{|c|c|c|}
\hline Ketuntasan & Jumlah Siswa & Persentase (\%) \\
\hline Tuntas & 27 & $93 \%$ \\
\hline Tidak Tuntas & 2 & $7 \%$ \\
\hline Jumlah & 25 & $100 \%$ \\
\hline
\end{tabular}

Sumber Data: Diolah dari data penelitian, tahun 2019

Dari tabel 2 di atas, terlihat bahwa jika dianalisis secara persentase maka ketuntasan belajar siswa mencapai $97 \%$. Dengan demikian maka indikator kinerja siswa sudah mencapai target dimana indikator kinerja yang ditentukan yaitu $80 \%$

\section{B. Pembahasan}

\section{Aktivitas Belajar Siswa}

Berdasarkan permasalahan awal tentang gambaran aktivitas belajar siswa dalam proses balajar mengajar pada mata pelajaran sosiologi diajar dengan menerapkan model pembelajaran CTL dapat dijelaskan pada hasil pengamatan disetiap siklusnya baik siklus I maupun siklus II yang menunjukan kearah yang lebih baik, dimana rata-rata aktivitas belajar siswa sebesar $66 \%$. Peningkatan aktivitas belajar siswa tersebut menunjukan adanya minat dan antusias siswa dalam mengikuti proses pembelajaran pada mata pelajaran sosiologi dengan penerapan model pembelajaran CTL. 
E-ISSN: 2502-6674

P-ISSN: 2502-6666

http://ojs.uho.ac.id/index.php/p_sejarah_uho

Pada siklus I ini berdasarkan hasil analisis deskriptif terhadap aktivitas siswa menunjukan ketuntasan belajar pada siklus I sebesar $70 \%$ yang belum mencapai skenario ketuntasan. Pada siklus I ada beberapa aktivitas siswa yang masih tergolong kurang dimana siswa belum terbiasa dengan model pembelajaranCTL. Berdasarkan hasil refleksi pada siklus I ditemukan ada beberapa aktivitas siswa yang belum terlaksana dengan baik. Olehnya itu dilakukan perbaikan pada siklus selanjutnya.

Pada siklus II dari hasil analisis deskriptif terhadap skor rata-rata aktivitas belajar siswa menunjukan peningkatan dibandingkan pada siklus I. Dimana pada siklus II pembelajaran sudah tercapai yaitu sebesar $100 \%$ dimana telah melampaui batas ketercapaian.

\section{Efektivitas Mengajar Guru}

Berdasarkan permasalahan kedua yaitu, bagaimana gambaran efektivitas mengajar guru dengan menerapkan model pembelajaran CTL. Dapat dijelaskan berdasarkan hasil pengamatan aktivitas mengajar guru pada tiap siklusnya baik siklus I maupun siklus II yang menunjukan peningkatan kearah yang lebih baik, dimana rata-rata efektivitas mengajar guru dapat dilihat pada tabel 2 dan 6. Pada siklus I analisa deskriptif efektivitas mengajar guru menunjukan persentase skor terlaksana masih cukup rendah yaitu $83, \%$. Hal ini dikarenakan pada siklus I efektivitas guru masih tergolong rendah.

Berdasarkan hasil refleksi terhadap efektivitas guru, dengan mengetahui kekurangankekurangan pada siklus I, guru memperbaiki cara mengajarkan materi pembelajaran yang sesuai dengan model pembelajaranCTL, sehingga diharapkan pada pertemuan selanjutnya diperoleh peningkatan pada efektifitas mengajar guru.

Pada siklus II efektivitas mengajar guru menunjukan peningkatan yang signifikan, dimana pada siklus II persentase skor terlaksana efektivitas mengajar guru memperoleh nilai sebesar $100 \%$ yang tergolong baik. Hasil analisis dan pengamatan pada siklus II ini menunjukan adanya peningkatan aktivitas mengajar guru dengan menerapkan model pembelajaran CTL sehingga peneliti berhenti pada siklus II ini.

\section{Hasil Belajar Siswa}

Berdasarkan permasalahan ketiga yaitu Apakah penerapan model pembelajaran CTL.dapat meningkatkan hasil belajar sosiologi pada siswa kelas XI IPS-3 SMA Negeri 1 Wangi-Wangi? Dapat dijelaskan bahwa berdasarkan hasil analisis deskriptif kuantitatif yang dilakukan pada hasil belajar siswa pada setiap siklusnya mengalami peningkatan kearah yang lebih baik. Pada siklus I hasil tes belajar siswa diperoleh nilai minimum 20; nilai maksimum 99; rata-rata hasil belajar siswa sebesar $88 \%$ dimana 27 orang yang tuntas secara klasikal dan 2 orang lainnya tidak tuntas secara klasikal atau nilainya tidak mencapai KKM yang ditentukan oleh sekolah. Persentase ketuntasan pada siklus I ini belum mencapai target peneliti yaitu mencapai ketuntasan hasil belajar secara klasikan minimal 80\%

Data tersebut terlihat bahwa dalam pembelajaran ini tampak bahwa siswa kurang membaca buku teks terkait yang dipelajari dan juga siswa kurang aktif dan kurang kompak dalam berdiskusi. Setelah melakukan analisis dan refleksi hasil belajar siswa pada siklus I, guru mata pelajaran sosiologi dan peneliti mencoba melakukan perbaikan dalam proses belajar mengar agar pada siklus selanjutnya siswa yang mengalami ketuntasan belajar dapat meningkat seperti yang diharapkan. Pada siklus II berdasarkan hasil tes belajar siswa pada siklus ini terlihat bahwa hasil belajar siswa memperoleh nilai minimum 50; nilai maksimum 99; rata-rata hasil belajar siswa sebesar $88 \%$ dimana 27 orang yang tuntas secara klasikal dan 2 orang lainnya tidak tuntas secara klasikal atau nilainya tidak mencapai KKM yang ditentukan oleh sekolah. Persentase ketuntasan pada siklus II sudah mencapai target yaitu $80 \%$. Dengan hal ini maka peneliti dianggap berhasil mencapai targetnaya.

Peningkatan hasil belajar dari siklus I kesiklus II ini dikarenakan peneliti telah melakukan perbaikan atau refleksi dari siklus sebelumnya sehingga siswa menjadi berani dalam mengemukakan pendapatnya, dan mampu memahami materi yang didapatkan dan mencoba 
menghubungkan materi yang didapat dengan pengalaman atau pemahaman yang siswa dapatkan dikehidupan nyata. Sehingga siswa lebih faham dengan materi yang di bahas dan hasil belajarpun meningkat. Dalam penelitian ini keberhasilan siswa dalam tes hasil belajar siklus II memberikan gambaran bahwa penerapan model pembelajaran CTL dapat meningkatkan hasil belajar siswa. Dengan demikian jawaban atas permasalahan telah terungkap yaitu dengan penerapan model pembelajaran CTL dapat meningkatkan hasil belajar sosiologi pada siswa kelas XI IPS-3 SMA Negeri 1Wangi-Wangi.

\section{PENUTUP}

Berdasarkan rumusan masalah dan analisis data dengan menerapkan model pembelajaran CTL pada mata pelajaran sosiologi pada siswa kelas XI IPS-3 SMA Negeri I Wangi-Wangi dapat ditarik kesimpulan yaitu: pertama aktivitas belajar siswa kelas XI IPS-3 SMA Negeri 1 WangiWangi dalam pembelajaran dengan menerapkan model pembelajaran CTL dari siklus I sampai dengan siklus licenderung mengalami peningkatan dimana dapat dilihat dari presentase terlaksana aktivitas belajar siswa dimana siklus satu sebesar $70 \%$ yang termasud cukup, dan pada siklus II mengalami peningkatan sebesar $100 \%$ yang berkategori baik.

Kedua efektivitas mengajar guru dalam pembelajaran sosiologi pada siswa kelas XI IPS-3 SMA Negeri 1 Wangi-Wangi dengan menerapkan model pembelajaran CTL pada siklus I sampai dengan siklus II mengalami peningkatan, dimana dilihat dari presentase keterlaksanaan efektivitas mengajar guru pada siklus I 83\% yang termasuk cukup dan pada siklus II meningkat menjadi $100 \%$ yang berkategori baik.

Ketiga ketuntasan hasil belajar siswa pada kelas XI IPS-3 SMA Negeri 1 Wangi-Wangi dengan menerapkan model pembelajaran CTL pada siklus I diperoleh nilai minimum 20 dan maksimum 99 dengan nilai rata-rata 69dengan ketuntasan secara klasikal mencapai 66\% sedangkan nilai pada siklus II meningkat menjadi nilai minimum 50 dan maksimal 99 dengan nilai rata-rata 88 dengan ketuntasan secara klasikal mencapai 93\%.

\section{DAFTAR PUSTAKA}

Arikunto, S. 2006. Metode Penelitian Kualitatif. Jakarta: BumiAksara

Arikunto, Suharsimi. 2006. ProsedurPenelitian: Suatu Pendekatan Praktik (Edisi Revisi VI). Jakarta: Rineka Cipta.

Hendyat, Soetopo. 2005. Pendidikandan Pembelajaran: Teori, Permasalahan dan Praktek, Malang: UMM press.

Sani, Ridwan Abdullah. 2013. InovasiPembelajaran. Jakarta. Bumi Aksara.

Sugioyono. 2006. Metode Penelitian Kuantitatif, Kualitatif, dan R\&D. Jakarta: Alfabeta 